\section{Archæological Exploration in Persia}

MUCH as it may be regretted that the British School of Archæology in Iraq (Gertrude Bell Memorial), in accordance with the decision announced at the end of last season, will not itself be responsible for expeditions of archæological exploration in its special province, pending more satisfactory arrangements under the antiquities laws of the country, the announcement of the grant of $£ 500$ from the funds of the School to Sir Aurel Stein towards the cost of excavating mounds in south-western Persia will afford archæologists some measure of consolation for the suspension of activities in northern Iraq. The archæological work which Sir Aurel proposes to carry out with the assistance of this grant is in continuation of certain investigations which he has made during the past two seasons in south-eastern Persia, where a number of early sites were examined. $\mathrm{He}$ will cover a field in which it is anticipated that much needed evidence will be obtained bearing on the relations of the early culture of Elam and possibly, it is hoped, the relationship of the Indus valley civilisation to that of western Asia - at the moment the most intriguing of the problems of Middle Eastern prehistory. It is also announced that the British School has made a grant of $£ 100$ towards the expenses of the short season of excavation at Ur which is now opening.

\section{Prehistoric Art in the Libyan Desert}

SHоuld preliminary announcements be confirmed by subsequent examination of the evidence, a further link in the relations between the prehistoric art of northern Africa and the Bushman art of South Africa is afforded by discoveries made by Dr. Leo Frobenius in the Libyan Desert. Dr. Frobenius, who has just returned from his eleventh expedition to Africa, reports, according to a Frankfort dispatch in the Times of December 28, that he has discovered in the Auwenat massif a centre of supplies for the stone implement factories of various parts of North Africa, with evidence in the form of rock-drawings, stone tools and traces of pottery of two distinct cultural periods, the older coming from Lower Egypt in the north, the later, of a character hitherto unknown, coming from the south. Moving south to the oasis of Selimah in northern Kordofan, Dr. Frobenius discovered a new southern culture with a ceramic industry dating from between 6000 and 4000 B.C. in an area which he regards as having been the valley of a third or 'Yellow' Nile. On the route to this centre, 44 stone impiement factories were discovered as well as several hundred rock-drawings, representing men and animals engaged in various activities. It is maintained that these discoveries throw a new light on the relations of the art of North Africa, East Spain and South Africa, while the dating of the 'factories' makes it possible to determine the direction of culture drift.

Presentation to Sir Herbert Jackson, K.B.E., F.R.S.

THE Council of the British Scientific Instrument Research Association held an informal luncheon at the Connaught Rooms on December 21 in honour of Sir Herbert Jackson, who occupied the position of Director of Research of the Association from its beginning in 1918 until July 31, 1933. Some thirty members of council and friends, representing all sides of the scientific instrument industry, attended. After the luncheon, Sir Herbert Jackson was presented with a gold minute-repeater watch and a vase of carved white jade, and Lady Jackson received a pair of ivory-backed brushes and a mirror. Mr. Conrad Beck, in proposing the toast of Sir Herbert and Lady Jackson, spoke of the valuable work which Sir Herbert Jackson had done and of the friendly relations which had existed between Sir Herbert and all the members of the Association. Sir Frank Smith and Mr. H. T. Tizard both referred to the wide range of Sir Herbert's activities and to the wealth of helpful suggestion which he could invariably bring forward in discussions on non-technical as well as on technical matters. In the remarks made by Mr. R. S. Whipple, Mr. F. Twyman and Mr. J. Hasselkus, special tribute was paid to Sir Herbert's power of inspiring self-confidence in those with whom he came into contact, and to the encouragement he had always given to instrument makers not to be satisfied with an instrument that was good enough, but to produce an instrument which was really outstanding. High tribute was paid also by all the speakers, to Lady Jackson, who shares the affection in which Sir Herbert himself is held. Sir Herbert Jackson, after thanking the council and members of the Association for their expressions of appreciation and for their gifts, referred to the assistance and co-operation which he had received from the industry itself, and to the spirit of enterprise which animated the industry: without these it would have been possible to do but little.

\section{The Physical Society's Exhibition}

THE catalogue of the Annual Exhibition of Scientific Instruments and Apparatus to be held at the Imperial College by the Physical Society on January $9-11$ is an octavo volume of 184 pages, the trade section occupying 148 , the research and experimental section 26 , and the index to the trade section 5 pages. Reference to the exhibits, the stands and the firms exhibiting has been greatly facilitated by the number of the stand and the name of the firm being printed at the head of each page. A considerable number of illustrations are provided, but there is still a number of firms satisfied with showing little more than the outside appearance of a piece of apparatus, for example, a box on the top of which are a handle for carrying, a small window and a few terminals, instead of a diagram of its mechanism or a view of its interior. As a contrast, the descriptions in the research and experimental section are full of the information which a potential user of an instrument or a method requires in order to determine whether it will suit his purpose. In the trade section, instruments which have not been exhibited previously are marked with an asterisk and on the stalls with a red star. Many of them are connected with branches of physics which have in recent years become important in industry, for 